\title{
A SOCIOLINGUISTICS ANALYSIS OF ADRESSING TERM USED IN AISYAH: BIARKAN KAMI BERSAUDARA MOVIE
}

\author{
Neneng Meilinda Nur Syahidawati ${ }^{1}$, Aseptiana Parmawati ${ }^{2}$ \\ ${ }^{1}$ IKIP Siliwangi \\ ${ }^{2}$ IKIP Siliwangi \\ ${ }^{1}$ melinnursya@gmail.com, ${ }^{2}$ aseptianaparmawati@gmail.com
}

\begin{abstract}
The purpose of this research, namely analyzing Aisyah : biarkan kami bersaudara movie to find out the type of addressing term used in this movie. This research uses descriptive qualitative method taken from the dialogue spoken by the characters in Aisyah : biarkan kami bersaudara movie. In this movie five addressing terms are found, namely the addressing term using name, addressing term using kinship name, addressing term using intimacy name, addressing term using respect name, and addressing term Using mockery name. The most commonly used term is addressing term using name
\end{abstract}

Keywords: Adressing Term, Movie

\section{INTRODUCTION}

Humans are social beings (Otoman, 2018). As social beings, of course humans also have social behaviour. Social behaviour is studied in linguistics, namely sociolinguistics. According to David Crystal (1980) cited in Pangaribuan (2010) sociolinguistics is a branch of language that starts from Language and social or society.

As social beings, humans cannot be separated from language. Humans can receive and provide information through language (Wardani, 2010). Because language is a tool sent by humans. Continuity of communication will be easier if you use Language, and will fail if without Language. Therefore, communicating using language is one part of the interaction that humans do as social beings (Adhalina, 2011).

Sociolinguistics tends to explain how people communicate in terms of social context or function. In the book An Introduction to Sociolinguistics written by Wardaugh, expressing in sociolinguistics there is a part called the addressing term. Addressing term is a rule in society that uses the way someone talks to the same person but asks for something different. During a call, the caller has a separate style and usually uses the addressing term for mutual calls during a conversation. This is due to the social context. (Rifai \& Prasetyaningrum, 2016).

Wardaugh also explains some words that can be used by the community for title (T), with first name (FN), with last name (LN), by nickname, by some combination of these (Wardaugh, 2000).

There are several previous studies related to the topic of addressing terms to support current research. The first research was conducted by Dian Muhammad Rifai and Sevian Tri Prasetyaningrum (2016) entitled "A Sociolinguistic Analysis of Addressing Terms Used in Tangled Movie Manuscript". Showing that the results of the research there are five types of 
addressing terms used in Tangled movie scripts, such as the addressing term using name, addressing term using kinship name, addressing term using intimacy name, addressing term using respect name, and addressing term Using mockery name.

The second research, conducted by Adi Widiatmaja (2014), entitled "A Sociolinguistic Analysis of Address Term Performed by the Main Character in Runway Jury Movie". Showing that the results of the research are seven types of addressing terms used in Runway Jury movie, namely first name (FN), title plus last name (TLN), title (T), last name (LN), special nickname (SN), pet name (PN), and kinship term (KT).

The third research, conducted by Eis Naeni (2011) entitled "The Sociolinguistics Analysis of Politeness in Addressing Terms Used in Final Destination 2 Movie Manuscript". Showing that the results of the research found five types of addressing terms used, namely the addressing term using name, kinship, intimacy, respect and mockery.

Inspired by previous research, researchers will research two parts of sociolinguistics, namely addressing term and vernacular words in Aisyah: Biarkan Kami Bersaudara Movie. The purpose of this research is to find out movie the type of addressing term used and included in the vernacular language which the addressing term in Aisyah: Biarkan Kami Bersaudara Movie.

\section{METHOD}

This research used descriptive qualitative research design, because this research intends to find out the type of addressing term used in "Aisyah: Biarkan Kami Bersaudara" Movie. To collect data, researchers use the observation method to obtain appropriate dialogue. Before analyzing and collecting data for this research, there are several steps that must be taken, researchers must watch the movie first, observe all terms of addressing terms in "Aisyah: Biarkan Kami Bersaudara" Movie, then the data analyzed.

\section{RESULTS AND DISCUSSION}

\section{Results}

The type of addressing term found in the Aisyah : Biarkan Kami Bersaudara Movie is addressing term using name, Addressing term using kinship name, addressing term using intimacy name, addressing term using respect name, and addressing term using mockery name.

\section{Addressing Terms Using Name}

A : Pak Dadang, nanti bada magrib jangan lupa datang kesini ya.

$\mathrm{P} \quad$ : Iya, insyaallah neng.

I : Aisyah, ini wa Deden mau pulang. Sok atuh kamu ngomong, katanya mau cari lowongan kerja.

$\mathrm{P} \quad$ : Emangnya aisyah mau kerja di tempat ua?

I : Aisyah, kamu ngelamun? Kenapa ngelamun?

A : ya gitu mah, a jaya mau dipindahin tugas ke luar pulau jawa.

I : Mau disuguhin apa atuh si jaya?

J : eh eh gausah ibu atuh ih.

$\mathrm{P} \quad$ : Telfon wa Maman.

A : Wa Maman?

A : Pak Pedro, ini saya Aisyah

$\mathrm{P} \quad$ : Kamu sekarang dimana?

$\mathrm{P} \quad$ : Ibu guru, ini bapak kepala sekolah.

X : Saya Yohanes. 


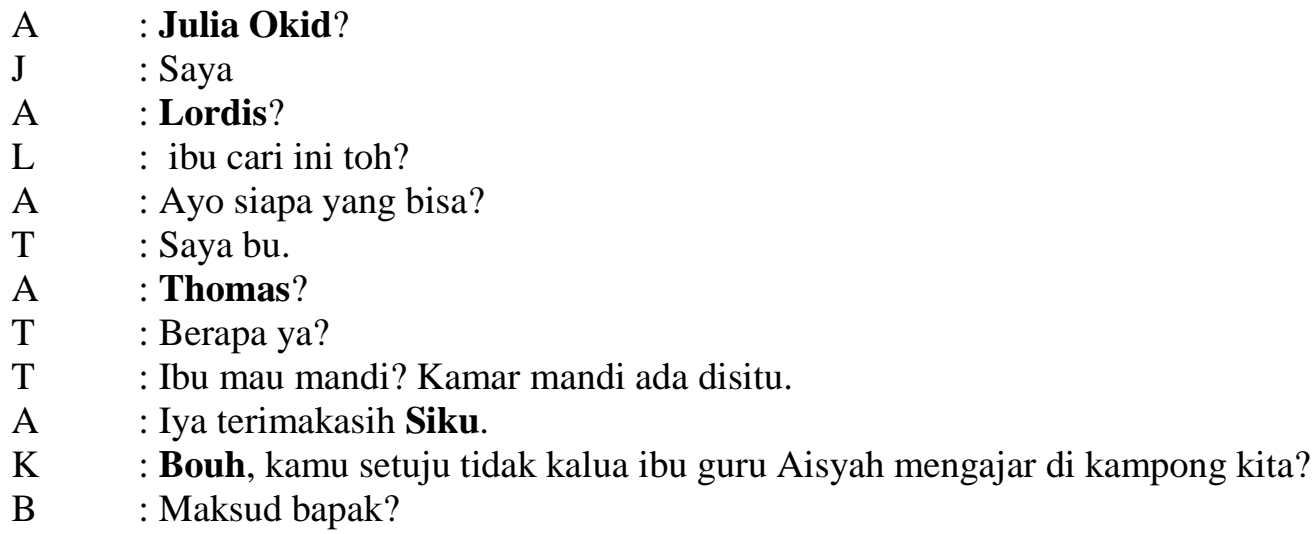

\section{Addressing Term Using Kinship Name}

B : Neng, duluan ya neng.

A : Mangga bi, hati-hati.

D : Emangnya aisyah mau kerja di tempat ua?

A : Engga uwa. Inimah simamah aja ngarang.

T : Neng, pamit dulu ya, assalamualaikum.

A : Nuhun teh.

A : Asa kurusan ya $\mathbf{a}$ ?

J : Iya gitu?

I : Aisyah.

A : Iya mah?

I : Bubur Kacang ijo disempen dimana?

A : Habis kayaknya mah.

A : Aa kan pernah bilang waktu itu sama aisyah. Iyah nanti aa kenalain sama pacar aa. Mana sampai sekarang, engga dikenal-kenalin.

J : Udah putus.

A : Mamah, tadi teteh di telefon sama yayasan mamah. Terus kata orang yayasannya ya minggu depan teteh udh mulai ngajar.

I : Alhamdulilah.

A : Mamah teh kenapa sih? Gitu pisan ngeliatin teteh.

I : Kalau kamu mau ambil keputusan yang penting, jangan sambal emosi atuh.

A : Memangnya paman tidak larang ketemu sama ibu guru?

L $\quad$ : Tadi pagi dia ditangkap polisi.

\section{Addressing Term Using Intimacy Name}

I : Lebih baik kamu pulang dari pada saya yang kesitu.

P : Tidak boleh begitu, cinta.

B : Neng, tadi mamah nyariin neng.

A : oh gitu.

$\mathrm{P} \quad$ : Guru ini nona

I : Oh kamu lebih pilih antar itu nona?

4. Addressing Term Using Respect Name

A : Pak, pagi pak.

$\mathrm{P} \quad$ : pagi

I : Selamat pagi ibu guru.

A : Pagi bu.

M : Selamat pagi, nai.

$\mathrm{P} \quad$ : Selamat pagi, mama dusun (Ibu Dusun).

M : Ibu guru ini bapak kepala sekolah.

X : Saya Yohanes. 
X : Belajarlah banak dari beliau, kalau kalian malas belajar, ibu guru Aisyah lebih senang pulang ke jawa.
A : : Tersenyum)
A : Mari ibu permisi.
I : Mari.
P : Maksudnya warga desa sini tergantung Bapak Dusun.
B : Masyarakat disini menerima ibu apa adanya, tanpa memandang agama.

\section{Addressing Term Using Mockery Name.}

J : Bukan maksud aa kaya gitu. Aa mah pengennya satu, tapi apa daya kalua misalkan tiba - tiba ada yang dating pengen dipacarin, yang satu pengen dilamar. Aa mah Cuma bisa pasrah.

$\begin{array}{ll}\text { A } & \text { : Geleh si aa mah. Meni so cakep pisan. } \\ \mathrm{J} & : \text { Neng itemanya. Cie item manis. } \\ \text { A } & : \text {......... }\end{array}$

Table 1. Analysis Type the Addressing Terms

\begin{tabular}{rlc}
\hline No & \multicolumn{1}{c}{ Type the Addressing Terms } & $\sum$ \\
\hline \multicolumn{1}{c}{ Addressing Terms Using Name } & 12 \\
1. ( Pak Dadang, Wa Deden, Aisyah, Jaya, Wa Maman Pak Pedro, & \\
& Yohanes, Julia Okid, Lordis, Thomas, Siku, Bouh ). \\
\hline 2. $\begin{array}{l}\text { Addressing Term Using Kinship Name } \\
\text { ( Bi, Uwa, Teh, A, Mah, Aa, Mamah, Teteh, Paman ). }\end{array}$ & 9 \\
\hline $\begin{array}{l}\text { Addressing Term Using Intimacy Name } \\
\text { ( Cinta, Neng, Nona ). }\end{array}$ & 3 \\
\hline $\begin{array}{l}\text { Addressing Term Using Respect Name } \\
\text { ( Pak, Ibu Guru, Mama Dusun, Bapak Kepala Sekolah, Beliau, Ibu, }\end{array}$ & \\
\hline & Kepala Dusun ). & 2 \\
\hline
\end{tabular}

\section{Discussion}

Based on the data analyzed, it shows that the results of this research are five types of addressing term. There are (1) addressing term using name, (2) addressing term using kinship name, (3) addressing term using intimacy name, (4) addressing term using respect name, (5) addressing term Using mockery name. When viewed from the book written by Wardaugh and the results of previous studies, there is a match between the material in the book, previous research and current research.

When compared with previous research, there are several similarities and differences. Based on research conducted by Dian Muhammad Rifai and Sevian Tri Prasetyaningrum (2016) entitled "A Sociolinguistic Analysis of Addressing Terms Used in Tangled Movie Manuscript". And based on research conducted by Eis Naeni (2011) entitled "The Sociolinguistics Analysis of Politeness in Addressing Terms Used in Final Destination 2 Movie Manuscript". Showing that the results of the research there are five types of addressing terms, such as the addressing term using name, addressing term using kinship name, addressing term using intimacy name, addressing term using respect name, and addressing term Using mockery name. 
Different from the research conducted by Adi Widiatmaja (2014), entitled "A Sociolinguistic Analysis of Address Term Performed by the Main Character in Runway Jury Movie". The results are seven types of addressing terms used in Runway Jury movies, namely first name (FN), title plus last name (TLN), title (T), last name (LN), special nickname (SN), pet name (PN), and kinship term (KT).

If in analyzing the addressing term in this research there are various types of addressing terms, namely the address using term found 12 data, addressing term using kinship name found 9 data, addressing term using intimacy name found 3 data, addressing term using respect name found 7 data, and addressing Using data mockery name found 2 data.

\section{CONCLUSION}

After analyzing the existing data, it is analyzing the addressing term used in the Aisyah : Biarkan Kami Bersaudara Movie. The researchers found several conclusions. First in this movie the researcher found five type of addressing terms used. Namely the addressing term using name, addressing term using kinship name, addressing term using intimacy name, addressing term using respect name, and addressing term Using mockery name. The most commonly used term is addressing term using name.

\section{ACKNOWLEDGMENTS}

The researcher would like to thank the lecturers who helped in completing this article project. First, Mrs. Ida Lisdawati who has given the task to make this article. Secondly Mrs. Aseptiana Parmawati for guiding me in perfecting this article project. The last, Mr. Usman Arifin has provided motivation and ways that can be done if the results of checking plagiarism exceed the maximum amount specified.

The Researchers also hope that this article can be useful for reading or other researchers in the future.

\section{REFERENCES}

Adhalina, N. (2011). The Different Languange Style and Language Function Between Students and Teachers in Updating Their Status in Facebook Webpage. Unpublished Thesis. Diponegoro University.

Naeni, Eis. (2011). The Sociolinguistics Analysis of Politeness in Addressing Terms Used in "Final Destination 2" Movie Manuscript. Salatiga: State Islamic Studies Institute (STAIN) of Salatiga.

Otoman (2018). Esensei Manusia sebagai Makhluk Sosial.

Pangaribuan, T. R. (2010). Hubungan Variasi Bahasa Dengan Kelompok Sosial Dan Pemakaian Bahasa. Jurnal Bahas, 20(01).

Rifai, D. M., \& Prasetyaningrum, S. T. (2016). A sociolinguistic analysis of addressing terms used in tangled movie manuscript. Jurnal Penelitian Humaniora, 17(2), 123-134.

Wardani, R. D. N. S. (2010). Karakteristik Pemakaian Gaya Bahasa dalam Wacana Stiker Kendaraan Bermotor (Tinjauan Sosiolinguistik) (Doctoral dissertation, Universitas Muhammadiyah Surakarta).

Wardhaugh, Ronald (2006). An Introduction to Sociolinguistics. Fifth Edition. Blackwell Publishing.

Widiatmaja, A. (2014). A Sociolinguistic Analysis of Address Terms Performed by the Main Character in Runaway Jury Movie. Bachelor thesis, UNY Yogyakarta. 